Nataliia Kryzyna1, Liudmyla Radchenko ${ }^{2}$

\title{
FACTORS OF INFLUENCE ON THE IMPLEMENTATION OF PUBLIC ADMINISTRATION IN THE FIELD OF SOLID WASTE MANAGEMENT
}

Keywords: public policy, public administration, state planning, household waste, solid household waste.

ABSTRACT: Ukraine, as a modern state governed by the rule of law, has chosen one of its priority areas of development - focus on the European Union (EU) by harmonizing modern Ukrainian legislation with European standards, adapting regulations, including solid waste (MSW).

The experience of many European countries in solving this problem indicates the level of environmental awareness and motivation of the population (Rezoljucija "Peretvorennja nashogho svitu: Porjadok dennyj u sferi stalogho rozvytku do 2030 roku”, 2015).

The current situation in Ukraine is characterized by the further development of environmental threats associated with solid waste,specifically non-compliance with environmental safety requirements when removing them and the lack of modern systems for their collection, recycling, utilization. In the absence of separate collection, the problem of dangerous waste management in the household is practically not solved.

In the developed countries, the EU member states, waste management according to the concept of "Zero Waste", that is "zero waste" and "zero loss" has become practical - this defines a new ideology of attitude to production and consumption waste.

1 Doctor of Sciences (Public Administration), Professor, Honored Doctor of Ukraine, Professor at the Department of Regional Management, Local Self-Employment and ManagementNational Academy of Public Administration under the President of Ukraine, kryzyna.np@gmail.com. ORCID: 0000-0003-2074-961X.

2 Postgraduate Student at the Department of Regional Management, Personal Learning and Management National Academy of Public Administration under the President of Ukraine, Lyuda.Radchenko2018@ukr.net. ORCID: 0000-0001-6196-6456. 
In contrast to European countries, Ukraine has a very low level of processing and utilization of solid waste and a high indicator of their burial in landfills. A significant number of landfills are overloaded; do not meet environmental and sanitary standards. In the field of solid waste management there is a dangerous situation, which is exacerbated every year, resulting in increasing danger to the environment, life and health of the population. Solving this problem requires effective action to implement state policy and governance in this industry.

Accumulation generation is increasing from year to year, while a significant share of this waste is disposed of in landfills and landfills that are improperly operated, which has a negative influence on the environment and human health.

Today, the system of solid waste management is ineffective in Ukraine, resource-intensive, does not prevent the negative impact of solid waste on the environment on the life and health of the population. This contradicts the legally defined goals and directions of state policy in this area. As a result, the territory of Ukraine is littered with solid waste, which can lead to a garbage collapse at both the regional and national levels.

Therefore, the solution of this problem at the state level should be carried out through the introduction of effective public administration through legislative regulation, adaptation and implementation of regulations and legislation of European countries.

\section{INTRODUCTION}

The problem of waste in Ukraine in general and in Kyiv region, is especially large and significant both due to the dominance of resourceintensive multi-waste technologies in the national economy and due to the lack of adequate response to its challenges for a long time. The problem of solid waste generation and accumulation still acute due to insufficient waste processing, lack of modern landfills and the necessity for reconstruction, reclamation of existing solid waste landfills that have exhausted their resources or are operated in gross violation of environmental safety.

The problem of solid waste is partially solved in cities, but it is becoming quite relevant for countryside. The ratio of solid waste generated in urban and countryside is $71.2 \%$ and $28.8 \%$ accordingly. Local governments do not take enough measures to introduce separate collection of solid waste.

It is necessary to develop mechanisms improving public administration in the field of solid waste management, as a unification of public administration and their interaction with other public authorities, due to the 
demands of international acts, organizational problems and purpose, tasks and functions of public administration in this field of activity. And determent by system of interconnected organizational and legal, institutional, innovative, financial and economic mechanisms.

The purpose of the study: to discuss the theoretical foundations of the factors influencing the implementation of public administration in the field of solid waste management on the example of Kyiv region.

To achieve this goal, it is necessary to solve several research problems:

1. To analyze the sphere of solid waste management in Kyiv region.

2. Investigate the factors influencing the implementation of public administration in the field of solid waste management.

Research methodology. Our research is based on the general scientific principles of conducting comprehensive research on public administration in the field of solid waste management. We used a set of complementary and interconnected general scientific and special research methods aimed at obtaining objective and reliable results. Particular we used the following theoretical and empirical research methods: dialectical method - to study the essence of public administration in the field of analysis of solid waste management - to ensure the integrity of the study; generalization method - for preparation of conclusions, proposals and recommendations.

\section{ANALYSIS OF THE SPHERE OF SOLID WASTE MANAGEMENT IN KYIV REGION. RESULTS OF THE RESEARCH}

Kyiv region is one of the leading regions of Ukraine. There are a lot of industrial enterprises, utilities, highways of international and national importance in this region.

The set of environmental protection measures includes several directions. For instance, protection of the air basin, water resources, soil conservation and forest resources (Ekopasport Kyivskoi oblasti, 2019).

Let's estimate an ecological situation in the Kiev area using two factors (indicators) (ecological loading, local ecological management) and corresponding parameters. 
The problem of waste is particularly large-scale and significant both due to the dominance of resource-intensive multi-waste technologies in the national economy, and due to the lack of adequate response to its challenges for a long time.

One of the most important environmental problems in the Kyiv region is the formation and accumulation of solid waste. Sanitary cleaning of cities and districts from solid waste is one of the most important elements and at the same time the most difficult problem of their livelihood. Waste generation increases from year to year, while a significant part of this waste is disposed of in landfills and dumps, which use unused forms, resulting in negative impacts on the environment, life and health of the population (Regional waste management plan of Kyiv region, 2018).

The problems of solid waste are partially solved in cities but are becoming quite relevant for rural areas.

The ratio of solid waste generated in urban and rural areas is 71.2 and $28.8 \%$, accordingly. However, if cities are almost completely covered by the system of collection and disposal of household waste, in rural areas this indicator does not exceed 60-70\% (Kontseptsiya vprovadzhennya suchasnoyi systemy povodzhennya z pobutovymy vidkhodamy v Kyyivskiy oblasti, 2019).

There is almost no organized removal of solid waste in rural settlements. There are no programs for solid waste management and sanitation schemes of settlements no registers of waste generation, treatment and disposal sites in most settlements. All this leads to the formation of natural disasters. landfills and worsens the sanitary condition of settlements.

Analyzing the dynamics of waste generation in the Kyiv region, there is a tendency to reduce the volume since 2012. However, waste management is in a terrible state, as $81 \%$ of the total amount of waste is disposed of, sent to landfills or landfills and only $18 \%$ is disposed of and $1 \%$ is incinerated (Figs. 1,2).

Solid waste management in Kyiv region is one of the priority and most important areas of both economic and environmental activities. It includes actions directed at preventing the generation of waste, its collection, transportation, storage, processing, use and disposal, which includes control over these operations and inspection at landfills (Fig. 3). 

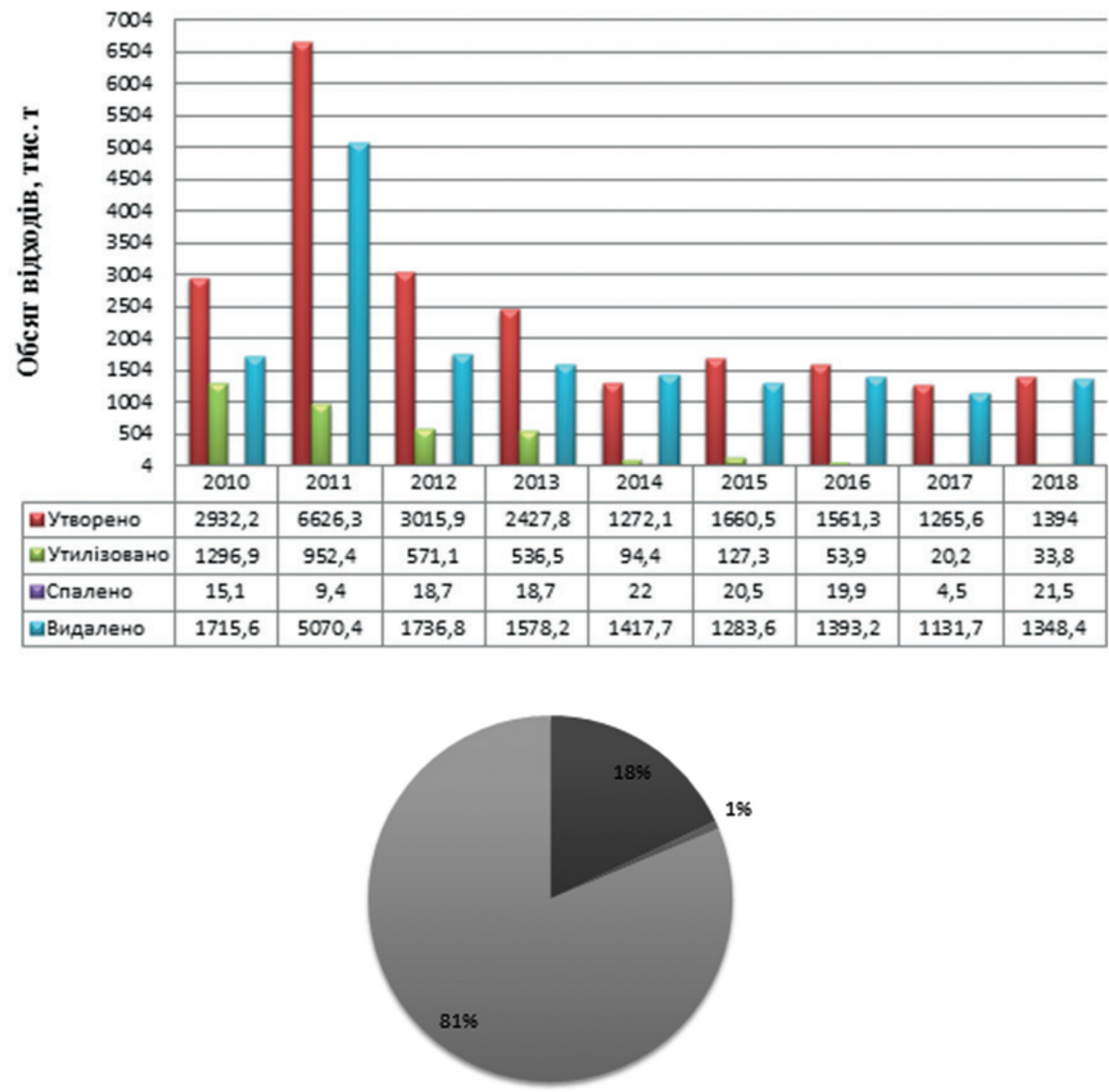

Fig. 1., 2. Dynamics of waste generation volumes and management in Kyiv region by years. (Ekopasport Kyivskoi oblasti, 2019).

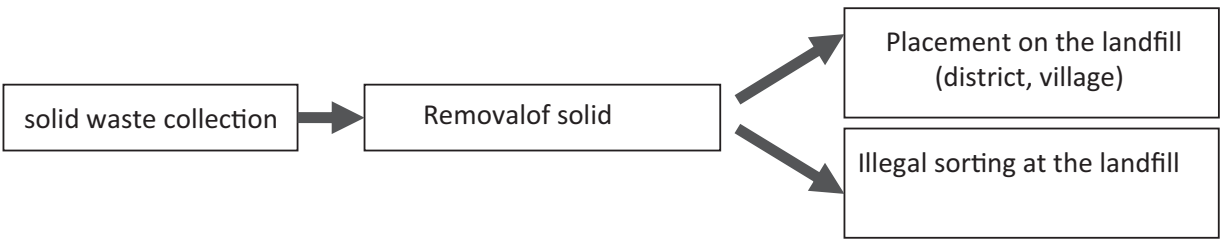

Fig. 3. The current state of waste management in the Kiev region (Kontseptsiya vprovadzhennya suchasnoyi systemy povodzhennya z pobutovymy vidkhodamy v Kyyivskiy oblasti, 2019). 
Disposable goods contribute to the growth of solid waste; packaging, which, moreover, modifies it. According to statistics, each person generates an average of 2 to $2.2 \mathrm{~m} 3$ of solid household waste per month, which tends to grow steadily.

The number of landfills is 37 units, occupying an area of about 268,077 ha, of which 12 (32.43\%) are overloaded, 36 units (97.29\%) do not meet environmental safety standards, usually due to insufficient control or lack of proper management system with solid waste (Kontseptsiya vprovadzhennya suchasnoyi systemy povodzhennya z pobutovymy vidkhodamy $\mathrm{v}$ Kyyivskiy oblasti,2019)

Most landfills in the Kyiv region do not meet sanitary requirements for landfill operation, and a significant number of landfills have already exhausted their resources and become a factor of anthropogenic pressure on the environment.

There is no universal method of solid waste management that would meet modern environmental and economic requirements. The most acceptable is a combined method, which involves the use of waste as a source of energy and secondary raw materials. It is the complex processing of solid waste, which includes sorting, heat treatment, fermentation and other processes, provides maximum environmental and economic efficiency (Kontseptsiya vprovadzhennya suchasnoyi systemy povodzhennya z pobutovymy vidkhodamy v Kyyivskiy oblast, 2019).

To date, solid waste is a mixture consisting of food waste, paper, cardboard, wood, scrap ferrous and nonferrous metals, bones, leather, rubber, textiles, glass, polymeric materials. But at the same time, in this mixture you can find mercury salts from batteries, phosphorous carbonates from fluorescent lamps, toxic chemicals contained in paint residues and solvents, varnishes and aerosols, batteries, etc. (Table 1).

Table 1. Morphological composition of solid household waste depending on the distance of settlements to the city of Kyiv

\begin{tabular}{|l|c|c|c|}
\hline & 50 км & 100 км & 150 км \\
\hline Paper & 12 & 10 & 10 \\
\hline Food waste & 13 & 12 & 10 \\
\hline
\end{tabular}




\begin{tabular}{|l|c|c|c|}
\hline & 50 км & 100 км & 150 км \\
\hline Textile & 6 & 5 & 7 \\
\hline Wood & 9 & 7 & 9 \\
\hline Polymers & 15 & 11 & 13 \\
\hline Rubber & 10 & 7 & 5 \\
\hline Glass & 12 & 12 & 2 \\
\hline Scrap metal & 8 & 4 & 34 \\
\hline Other wastes & 15 & 32 & 10 \\
\hline
\end{tabular}

Source: Ekopasport Kyivskoi oblasti, 2019.

From the above data, there is a tendency to reduce waste generation, which is caused, firstly, by a decrease in population in the region, and secondly, the general economic downturn in 2010-2018.

Utilization and incineration volumes during the studied period remain low and ranged from 1.5 to $19 \%$ in different years.

At the same time, there is also a tendency to reduce the share of recycled or incinerated waste.

The analysis of the state of the environment in the region shows that there are almost no natural components of the ecosystem that would not be subject to constant negative anthropogenic impact.

\section{FACTORS INFLUENCING THE IMPLEMENTATION OF PUBLIC ADMINISTRATION IN THE FIELD OF SOLID WASTE MANAGEMENT}

All the above indicates the presence of an institutional problem, including the problem of state planning, untimely management decisions at the stage of planning and approval of relevant measures and projects, as well as poor preparation of planning documents.

In addition, there are many of other problems and factors that affect the implementation of public administration in the field of solid waste management. We offer identifying factors and solving problems on the example of Kyiv region. 
Factors influencing the implementation of public administration in the field of solid waste management include:

- lack of motivational mechanisms for citizens;

- lack of guarantee for the development of waste processing enterprises;

- tariff grid as an instrument for motivating and building bilateral benefits "entrepreneur-community";

- tariff policy should not be unified throughout the country;

- territorial disproportion of location and uniformity of application of types of enterprises on waste processing;

- misuse of money from the Environmental Protection Fund and non-application of innovative technologies at the national level;

- failure to provide reliable reports on solid waste management, which is used in the preparation of the National Report on the State of the Environment in Ukraine and the National Report on the State of Man-Made and Natural Safety in Ukraine;

- Insufficient coordination of government activities, institutional imbalance, duration of management decisions;

Solving the identified problems:

- receiving a certain reward for citizens who honestly sort household waste (Germany has introduced a system of reducing the cost of rent for residents who sort waste);

- receiving preferences in the form of economic benefits (tax holidays to encourage and develop their business) for entrepreneurs working in the field of raw materials processing;

- Improving approaches to the formation of tariffs, which will encourage effective state regulation of solid waste management, it is proposed to develop bills: "On Amendments to the Budget Code of Ukraine" and "On Amendments to the Tax Code of Ukraine".

- planning of a network of collecting, storage, processing of waste each area has the features in formation of waste, processing, utilization. Local authorities are effectively deprived of the authority to issue permits for waste management operations, setting prices (tariffs) for recycling and disposal of household waste, and the relevant enterprises - the opportunity to receive from the popula- 
tion a legal and economically reasonable fee for their provision. This did not and does not encourage local governments to create conditions for attracting private investment in household waste recycling, and their activities were aimed at maximizing the cost of such services by creating only landfills - and this is not a panacea for solving the problem of waste management.

One of the proposals is the decentralization of powers to set tariffs for services for the processing and disposal of household waste and their transfer to local governments.

- use in Ukraine of modern technologies and European experience for the isolation and disposal of solid waste components in order to reduce the area of landfills and landfills;

- use of the best and latest technologies (use of plants that sort (separate) waste themselves, or arrange a biogas extraction system and use cogeneration plants);

- it is necessary to reform the collection, production and provision of statistics, publication to EU standards in the field of statistics (introduce mechanisms for internal control over the full implementation of the form 1-MSW "Report on solid waste management", propose to introduce an electronic monitoring information system areas of solid waste management;

- using the unification of duplication of functions to amend the provisions on the Ministry of Regional Development and the Ministry of Environment, approved by the Cabinet of Ministers of Ukraine from 30.04.2014 № 197 and from 21.01.2015 № 32, in terms of specifying the powers to implement public policy in the field of household waste management.

Utilization and incineration volumes during the studied period remain low and ranged from 1.5 to $19 \%$ in different years.

At the same time, there is also a tendency to reduce the share of recycled or incinerated waste.

- carrying out the procedures of tender selection of business entities for waste collection and removal determined by law,

- analysis of the implementation of indicators for waste collection and disposal, 
- the possibility of terminating contractual relations with waste carriers due to the detection of unsatisfactory performance of contractual obligations and conducting a re-tender,

- development and financing of programs for the functioning of housing and communal services of settlements for the organization of solid waste collection.

Tools used to manage the waste management system of the State Ecological Inspectorate of the Capital District:

- timely response to violations of environmental legislation in the course of economic activity by owners or users of landfills for solid waste.

Tools used to manage the waste management system of local state administrations:

- development and financing of programs for the functioning of housing and communal services of settlements for the organization of solid waste collection.

At present, the above tools are generally an effective mechanism for regulating waste management processes. At the same time, there are a number of problematic issues related to the insufficient level of funding for waste infrastructure development activities (Regional waste management plan of Kyiv region, 2018).

The actual financing of district needs is at the level of $12-17 \%$. Such a deficit of the ecological budget of the region is a consequence of the low rates of development of the real sector of the region's economy, in the structure of which a significant share is played by agricultural enterprises.

At present, in the structure of the Kyiv Regional State Administration, the Department of Housing and Communal Services and Energy Efficiency, the Department of Ecology and Natural Resources are involved in the systematic monitoring and elaboration of problematic issues of waste management (regulations and staffing. 


\section{CONCLUSIONS}

After all, overcoming the current catastrophic situation in Ukraine should be done by improving and innovatively transforming management systems and waste management into a modern, efficient, effective system. The updated integrated waste management system reduces the negative impact on the environment.

Environmental problems of Kyiv region. As all regions of Ukraine as well, are among the most pressing and need immediate solution at all levels, namely:

A) requiring a solution at the international level - bringing environmental legislation to the level of the European Union;

B) of national importance: problems of energy waste processing, and other industries;

C) of local significance: construction of modern landfills for the utilization of household waste and reclamation and reconstruction of existing landfills that have exhausted their resources or are operated in gross violation of environmental safety standards; introduction of separate waste collection from the population; liquidation of unauthorized landfills;

D) the solution of which does not require the involvement of significant material (financial) resources: certification of solid waste disposal sites rural, township and municipal landfills; preservation of greenery; increasing the area of nature reserve facilities; development of schemes of sanitary cleaning of settlements and rules of improvement of territories of settlements; holding educational activities.

All the above indicates the presence of an institutional problem, including the problem of state planning, untimely management decisions at the stage of planning and approval of relevant measures and projects, as well as poor preparation of planning documents.

Prospects for further research. In Ukraine, it is necessary to create a legislative, regulatory and technical framework, using the guidelines of European legislation in the field of waste management, which are part of the $4 \mathrm{R}$ system: reduce - reduce the amount; reuse - reuse; recycle - to recycle; recover - to benefit. The implementation of these principles 
involves the introduction of a system of clear actions focused on the expected and as a result - reducing pressure on the environment. These actions must be carried out at all levels of government - from local to state.

\section{BIBLIOGRAPHY:}

Bakumenko V. D., Usachenko L. M., Chervjakova O. V. (2013). Teoretychni zasady derzhavnogho upravlinnja [Theoretical principles of public administration] Kyiv: Interservis. [in Ukrainian].

Ekopasport Kyivskoi oblasti (2019) [Eco-passport of Kyiv region (2019)]. Departament ekologii ta pryrodnych resursiv KODA [Department of Ecology and Natural Resources KODA] Downloaded from: http://ecology-kievoblast.com.ua/Home/ StateOfEnvironment $/ 48$

Kontseptsiya vprovadzhennya suchasnoyi systemy povodzhennya z pobutovymy vidkhodamy v Kyyivskiy oblasti (2019) [Concept introduction of a modern system of household waste management in the Kiev region] Departament ekologii ta pryrodnych resursiv KODA [Department of Ecology and Natural Resources KODA]. Downloaded from: http://koda.gov.ua/normdoc/pro-skhvalennya-proektu-programisocia-5/

Pro osnovni zasady (stratehiyu) derzhavnoyi ekolohichnoyi polityky Ukrayiny na period do $2030 \mathrm{roku}$ [On the basic principles (strategy) of the state environmental policy of Ukraine for the period up to 2030] Zakon Ukrayiny vid 28.02.2019, No. 2697-VIII [Law of Ukraine from 28.02.2019, No. 2697-VIII] Ofits. veb-sayt Verkhov. Rady Ukrayiny [Officer. website Verkhov. Council of Ukraine]. Downloaded from: https:// zakon.rada.gov.ua/laws/show/2697-19.

Regional waste management plan of Kyiv region (2018) [Regional waste management plan of Kyiv region (2018)] Departament ekologii ta pryrodnych resursiv KODA [Department of Ecology and Natural Resources KODA]. Downloaded from: http:// ecologykievoblast.com.ua/Home/StateOfEnvironment/50

Rezoljucija "Peretvorennja nashogho svitu: Porjadok dennyj u sferi stalogho rozvytku do 2030 roku" [Resolution "Transformation of our world: Order of the day in the sphere of sustainable development until 2030"] Gheneraljna Asambleja OON (2015) [UN General Assembl]. Downloaded from: http://sdg.org.ua/ua/ resources-2/344-2030-2015 